腔扁平上皮癌における頸部郭清術施行例の臨床統計的検討

矢島幹人・举村俊一・根橋秀一郎・砂田 修
田村 稔・倉科憲治・武田 進・小谷
山朗
山崎 正

\title{
Clinicostatistical study on the cases for radical neck dissection in squamous cell carcinoma of the oral cavity
}

\author{
Mikito Yajima - Toshikazu Minemura - Shuichiro Nebashi \\ Osamu Sunada - Minoru Tamura - Kenji Kurashina \\ Susumu TAKeda - Akira Kotani - Tadashi Yamazaki*
}

\begin{abstract}
Clinicostatistical study was made about 70 patients with squamous cell carcinoma of the oral cavity (including maxillary sinus and oropharynx) who underwent radical neck dissection between 1978 and 1987 in our department.

Metastasis to the cervical lymph nodes was histologically confirmed in 42 patients (60\%). In 13 of the cases, late metastasis occurred. The carcinomas of the buccal mucosa most frequently metastasized to the regional lymph nodes because many of them invaded the surrounding tissues. The ratio of late metastasis was highest in carcinoma of the tongue. As to distribution of involved lymph nodes (UICC 1978), the majority were recognized in Level I and/or Level II. In only two cases, they were distributed in Level IV (supra clavicle nodes).

Twenty-five patients died of carcinoma. Uncontrolled cervical lymph nodes matastasis caused death in 7 cases. Clinical course of patients with advanced cancer (T 4, N 3), contralateral neck matastasis and involved lymph nodes in Level IV was not very good. Extra lymph node invasion related mainly to the recurrence rate of the matastatic tumor. A tendency was indicated that the prognosis was worse as the number of involved nodes, matastatic sites and lower level of cervical nodes increased.

The comulative five-year-survival rate was $60.1 \%$ in patients without metastasis and $54.4 \%$ with metastasis. - Although there was no significant difference between them, that of patients with late metastasis was extremely poor (14.4\%). 7 cases of these patients were dead and moreover distant matastasis was recognized in 6 cases.

Up to date, the needling irradiation therapy in carcinoma of the tongue and therapeutic radical neck dissection was performed in our clinic. Late cervical metastasis after treatment for primary tumor seemed to be controlled by careful follow-up. However, according to the results,prophylactic neck dissection should be considered especially in high grade malignant tumors.
\end{abstract}

信州大学医学部宷科口腔外科学教室

(主任：小谷 朗教授)

* 小諸厚生総合病院遒科口腔外科

（主任：山崎 正医長）

Department of Dentistry and Oral Surgery,

Shinshu Uriversity Schoo! of Medicine (Chief:
Prof. Akira Kotani)

* Department of Dentistry and Oral Surgery, Komoro Kousei General Hospital (Chief: Tadashi Yamazaki)

受付日：昭和63年10月11日 
Key words: radical neck dissection (RND)（頸部郭清御）, squamous cell carcinoma（扁平上 皮癌), oral cavity (口腔)

\section{緒訔}

口腔恶性腫瘍の治療において，原発巣とともに頸部り ンパ節転移の制御は重要な課題である。近年, 画像診断 学の発展や再建外科の進歩に伴い, 手術範囲が拡大し, 局所治瘉率は向上しつつあるが，いまたに頸部りンパ節 転移により不幸な転帰をとる例も少なくない。

当科では, 従来より頸部リンパ節転移に対し, 治療的 全頸部郭清術を原則として実施してきた。今回, 著者ら は現在までの口腔癌治療の再検討と今後の治療方法の指 針とすべく, 頸部郭清術施行例の臨床統計的検討を行っ たので報告する.

\section{対}

象

対象は，1978年 1 月より1987年12月までの10年間に， 信州大学附属病院歯科口腔外科を受診した口腔扁平上皮 癌一次症例 124 例（上顎洞，中咽頭を含む）の5ち, 頸 部郭清術を施行した70例（56.5\%）であり，性別は男性 38例, 女性 32 例 (1.19:1), 初診時年齡は 37歳〜79 歳 (平均62歳) であった。

原発部位（表1）では, 舌が36例と最も多く，次いで 下顎歯肉, 頓粘膜, 口底の順で, この 4 者で全体の87.3 \%を占めていた，1978年， UICC による TNM 分類 ${ }^{1)}$ （表 2 ）では, T 2 が 25 例と最も多く， N分類では， N （+）例か 41 例 $(58.6 \%)$ を占め，その大多数は N1 で あった，N2は1例のみであったが， Tが進展するにつ れて，N3 がふえる傾向がみられた，遠隔転移は全例之 むにみられなかった。なお，上顎洞癌は AJC 案 ${ }^{2)}$ に従 い, 中咽頭癌の 2 例はともに舌根部原発であった。

\section{郭 清 術式}

当科での頸部郭清術は原則として治療的全頸部郭清術 であり，63例（90\%）を占めていた。このうち反対側上 頸部郭清術の併用が12例, 両側全頸部郭清術（異時期） が 3 例あった（表 3 ）。予防的郭清術を実施した 5 例は， 下顎歯肉, 口底原発各 2 例, 頓粘膜原発 1 例で, いずれ も臨床的に転移を認めないが，原発巣の切除と同時に頸 部郭清術を行い，筋皮弁にて即時再建した症例である. 全頸部郭清術は，治療的，予防的いずれの場合もすべて 通常の全頸部郭清術であり，保存的または機能的郭清術 は行わなかった。 上頸部郭清術のみを実施した 3 例の 5ち 1 例は, 胸鎖乳突筋皮弁にて即時再建した症例であ
表 1 原発部位別分類

\begin{tabular}{|c|c|}
\hline 舌 & $36(51.5 \%)$ \\
\hline 下顎蒾肉 & $12(17.2 \%)$ \\
\hline 煩 粘 暯 & $8(11.5 \%)$ \\
\hline 口底 & $5(7.1 \%)$ \\
\hline 上顎歯肉 & $1(1.4 \%)$ \\
\hline 上 顎 洞 & $6(8.5 \%)$ \\
\hline \multirow[t]{2}{*}{ 中 咽 頭 } & $2(2.8 \%)$ \\
\hline & $70(100 \%)$ \\
\hline
\end{tabular}

表 2 TNM 分類

\begin{tabular}{l|r|r|r|r|r}
\hline & N 0 & N 1 & N 2 & N 3 & \\
\hline T 1 & 8 & 5 & & & 13 \\
T 2 & 14 & 9 & 1 & 1 & 25 \\
T 3 & 3 & 10 & & 1 & 14 \\
T 4 & 4 & 7 & & 7 & 18 \\
\hline & 29 & 31 & 1 & 9 & 70 \\
\hline
\end{tabular}

\begin{tabular}{cl|r}
\multicolumn{2}{c}{ Stage 分類 } \\
\hline Stage & I & $8(11 \%)$ \\
& II & $14(20 \%)$ \\
III & $27(39 \%)$ \\
IV & $21(30 \%)$ \\
\hline & $70(100 \%)$ \\
\hline
\end{tabular}

表 3 郭清術式

\begin{tabular}{|c|c|c|c|c|}
\hline & & 片側 & 両側 & \\
\hline 治療的 & $\begin{array}{l}\text { 全頸部郭清脯 } \\
\text { 上頸部郭清訹 }\end{array}$ & $\begin{array}{c}60 * \\
2\end{array}$ & 3 & 65 \\
\hline \multirow[t]{2}{*}{ 予防的 } & $\begin{array}{l}\text { 全頸部郭清術 } \\
\text { 上頸部郭清術 }\end{array}$ & $\begin{array}{l}4 \\
1\end{array}$ & & 5 \\
\hline & & 67 & 3 & 70 \\
\hline
\end{tabular}

* 反対側上頸部郭消術併用 12 例を含む

他は全身的条件などにより全頸部郭清術が実施できなか った症例である。なお，今回の症例にはリンパ節摘出術 り，は含まなかった。 
表 4 原発部位別転移頻度

\begin{tabular}{|c|c|c|c|}
\hline & 症 例 & 転移例 & 陽性率 $(\%)$ \\
\hline 舌 & 36 & 23 & 64 \\
\hline 下顎茵肉 & 12 & 6 & 50 \\
\hline 煩 粘 膜 & 8 & 6 & 75 \\
\hline 口底 & 5 & 1 & 20 \\
\hline 上顎畨肉 & 1 & 1 & 100 \\
\hline 上顎 洞 & 6 & 4 & 67 \\
\hline \multirow[t]{2}{*}{ 中咽頭 } & 2 & 1 & 50 \\
\hline & 70 & 42 & 60 \\
\hline
\end{tabular}

表 5 T 分類別転移頻度

\begin{tabular}{c|c|c|c}
\hline & 症 例 & 転移例 & 陽性率 (\%) \\
\hline T 1 & 13 & 8 & 62 \\
T 2 & 25 & 20 & 80 \\
T 3 & 14 & 6 & 43 \\
T 4 & 18 & 8 & 44 \\
\hline & 70 & 42 & 60 \\
\hline
\end{tabular}

表 $6 \mathrm{~N}$ 分類別転移頻度

\begin{tabular}{|c|c|c|c|c|}
\hline & & 症 例 & 転移例 & 陽性率 $(\%)$ \\
\hline \multirow[t]{2}{*}{ No } & 予防郭清例 & 5 & 0 & \multirow{2}{*}{45} \\
\hline & 二次郭清例 & 24 & $13^{*}$ & \\
\hline $\mathrm{N} 1$ & & 31 & 19 & 61 \\
\hline $\mathrm{N} 2$ & & 1 & 1 & 100 \\
\hline \multirow[t]{2}{*}{ N3 } & & 9 & 9 & 100 \\
\hline & & 70 & 42 & 60 \\
\hline
\end{tabular}

* 後発転移症例

\section{結}

\section{果}

\section{1. 頸部リンパ節転移の様相}

70例中組織学的に転移を認めた症例は42例（同側転移 35 例，反対側転移 7 例）あり，全体の転移陽性率は $60 \%$ であった。

原発部位別（表 4）では，上靧崡肉 1 例を除くと，頓 粘膜か $75 \%$ と最も高く, 以下，上顎洞 $67 \%$, 舌 $64 \%$ の順 で，口底は $20 \%$ と低い陽性率であった。

T分類別（表 5 ）では，T 2 が80\% と最も高く，次い で T 1 か $62 \%$ と，T 3，T 4 より高い傾向を示し，Tの 進展と転移率との間に相関はみられなかった。

$\mathrm{N}$ 分類別（表 6) では，初䛦時 N0 と猃断され，原発 巣治療後に転移が疑われるようになって頸部郭清を行っ
表 7 Stage 別転移頻度

\begin{tabular}{r|r|c|c}
\hline & 症 例 & 転移例 & 陽性率 (\%) \\
\hline Stage I & 8 & 4 & 50 \\
II & 14 & 9 & 54 \\
II & 27 & 18 & 67 \\
IV & 21 & 11 & 52 \\
\hline & 70 & 42 & 60 \\
\hline
\end{tabular}

表 8 分化度別転移頻度

\begin{tabular}{c|c|c|c}
\hline & 症 例 & 転移例 & 陽性率 (\%) \\
\hline 高 分化 & 49 & 29 & 59 \\
中 分 化 & 17 & 9 & 53 \\
低 分 化 & 4 & 4 & 100 \\
\hline & 70 & 42 & 60 \\
\hline
\end{tabular}

表 9 リンパ節転移部位

\begin{tabular}{|c|c|c|}
\hline & 症 例 & *5 年果積生存率(\%) \\
\hline Level I & $11(3)$ & \\
\hline II & 10 & 47.8 \\
\hline $\mathrm{I}+\mathrm{II}$ & 11 & \\
\hline $\mathrm{I}+\mathbb{I I}$ & 1 & \\
\hline $\mathbb{I I}+\mathbb{I I}$ & 4 & 112 \\
\hline II $+\mathbb{I}$ & 2 & \\
\hline $\mathrm{I}+\mathbb{I}+\mathbb{I}$ & 3 & \\
\hline
\end{tabular}

た二次郭清例が，29例中24例 $(82.8 \%)$ あり，このうち 13例飞組織学的に転移を認めた（以下，後発転移例とす る). 5 例は，予防的郭清を実施した症例で，いずれ も組織学的に転移を認めなかった。 また, 臨床的にN （十）と診断したが，組織学的に転移を認めなかった症 例 (false positive) は, N 1 において 31 例中 12 例 (39 \%）あり，N1 の転移陽性率は61\%であった，N 2，N 3 はいずれも $100 \%$ 転移陽性であった。全症例に対するリ ンパ節転移の正診率は，67\% (47/70) であり，false positive 33\% (23/70) で, false negative はなかった.

Stage 別（表 7) では，各 Stage 間で有意な差はみ られず， T分類と同様， Stage II， II の方が Stage $\mathbb{V}$ よりも高い傾向を示した。

原発栄の分化度と転移との関連（表 8 ）では, 低分化 型が 4 例と少ないものの，いずれも転移を生じていた。 高分化型と中分化型とでは，有意差はみられなかった。

リンパ節転移部位（表 9)については, 1978年, UICC の Level 分類” に従い検索した。 その結果, Level I 
表 10 リンパ節転移部位数

\begin{tabular}{c|c|c}
\hline & 症 例 & $* 5$ 年累積生存率 $(\%)$ \\
\hline 1 部 位 & 21 & 57.4 \\
複数部位 & 21 & 19.2
\end{tabular}

$* \mathrm{p}<0.05$

表 11 転移リンパ節個数

\begin{tabular}{l|c|c}
\hline & 症 例 & $* 5$ 年累䅣生存率 $(\%)$ \\
\hline 1 個 & 17 & 63.2 \\
2 & 11 & \\
3 & 9 & 18.7 \\
4 & 1 & \\
$5 \sim$ & 4 & \\
\hline
\end{tabular}

${ }^{*} \mathrm{p}<0.05$

表 12 原病死 25 例の腫瘍残存部位

\begin{tabular}{c|c|c}
\hline & 転移陽性例 & 転移陰性例 \\
\hline $\mathrm{T}$ & 2 & \\
$* \mathrm{~N}$ & 2 & \\
$\mathrm{M}$ & 7 & 2 \\
$\mathrm{~T}+\mathrm{M}$ & 3 & 3 \\
$* \mathrm{~N}+\mathrm{M}$ & 5 & \\
$\mathrm{~T}+\mathrm{N}+\mathrm{M}$ & 1 & 5 \\
\hline
\end{tabular}

* 頸部リンパ節転移の非制御例（7 例）

またはII に限局していたものが，32例で76.2\%を占め， Level IVまで転移したものはわずか 2 例のみであった。 この Level IVに転移した例（舌原発）は，いずれも鎖 骨上窩リンパ節に転移を認め，副神経リンパ節にはみら れなかった。 また，Level III，IVに転移した例では，必 ず Level I またはII に転移を形成していた。なお， オ トガイ下リンパ節に転移を認めた例は 3 例あり, 舌原発 2 例, 口底原発 1 例であった。

転移リンパ節部位数（表10）では，1 部位（Level I またはII）に限局した症例と，複数部位に転移した症例 とが半数ずつであった。転移リンパ節個数（表11）につ いて，1個のみ認められた症例は17例， 2 個以上認めら れた複数転移例は 25 例であり，最高は両側 7 個であっ た.

\section{2. 頸部郭清術後の臨床経過}

全症例の治療成績（1987年12月—現在）は，原病死 25例，他病死 4 例，生存41例で， 5 年累積生存率は57.9 \%であった，原病死25例について，死亡時点での腫瘍残 存部位（表12）をみると, 頸部リンパ節転移の非制御が

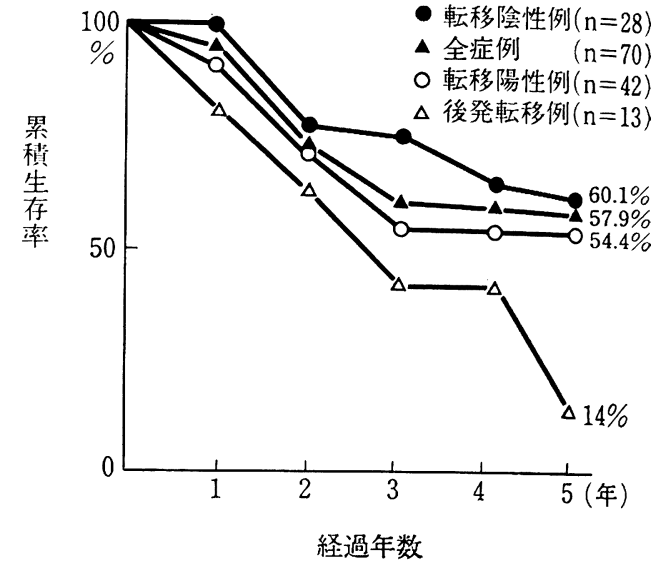

図 1 リンパ節転移と生存率

死亡へつながったと考えられる症例は 7 例あり, 全例転 移陽性例であった。これらは T 4 ・ N 3 の進展例, 反対 側・Level IVへのリンパ節転移，あるいはリンパ節外へ の浸潤を認めた症例であった。この中で, 初診時および 手術時 N 3 であった 15 例（表13）についてみると, 郭 清中転移リンパ節が破裂した症例が 2 例あり，治療成績 は原病死 9 例，担癌生存 2 例で経過不良であった。 た，反対側に転移または再発を認めた症例（表14）で は， 7 例中 5 例が死亡していた，特に患側の全頸部郭清 と同時に行った反対側の上頸部郭清後に再発した症例が 3 例あり，いずれも癌死した。初回手術後反対側に転移 を認めた時期は， $3 \sim 5$ か月（平均 4 か月）で，原発巣 の非制御例が 3 例あった。

リンパ節の転移部位（表 9）における Level I, I と Level III, $\mathbb{V}$, 部位数（表 10）に批ける 1 部位と複 数部位，個数（表 11）における 1 個と 2 個以上につい て，それぞれ 5 年累積生存率との関係をみると，いずれ も明らかな関連性を示し, 有意差 $(\mathrm{p}<0.05)$ がみられ た。

一方, 組織学的に転移を認めた転移陽性例と, 転移を 認めなかった転移院性例とを比較すると（図1），5年 累積生存率は $54.4 \%$ と $60.1 \%$ とで，転移陰性例の方が高 いものの，有意差はみられなかった。しかし，後発転移 例についてみると，5年累積生存率は14\%ときわめて低 い結果であった。そこで，後発転移13例中死亡した7例 につき，さらに検討した（表 15）。その結果，6例は舌 癌症例であり, 最短 2 か月から最長 24 か月で転移を生 じ，転移を認めた時点で固定性のリンパ節が触れたもの 3 例, 複数個のリンパ節腫脹を示すもの 6 例であった。 死亡時点で頸部に再発, 腫瘍の残存を認めたものは3 例 （症例 2，4，7）あり，原発巣の制御ができなかった 3 例を含めて 6 例に遠隔転移が生じていた。 また，これ らは頸部郭清術後， 2 か月〜 1 年 6 か月（平均10か月） 
表 13 N 3 症例（初診時 N 3: 9 例, 手術時 N 3:6 例)

\begin{tabular}{|c|c|c|c|c|c|c|}
\hline No. & 年齡 & 性 & 原発部位 $(T N)$ & 転帰 & （街後経過期間） & 腫瑒残存部位 \\
\hline 1 & 54 & 男 & 中咽 頭 (T4N3) & Ac & ( 2 加月) & $\mathrm{T}$ \\
\hline 2 & 64 & 女 & 下顎蔽肉 (T4N3) & Ao & ( 1 年 8 か月) & \\
\hline 3 & 54 & 男 & 上顎洞 (T4N3) & Dc & (4 か月) & $\mathrm{T}+\mathrm{N}+\mathrm{M}$ \\
\hline 4 & 67 & 男 & 舌 (T4N3) & Dc & (10か月) & M \\
\hline 5 & 50 & 男 & 舌 (T4N3) & Ao & ( 2 年 7 か月) & \\
\hline 6 & 71 & 男 & 上顎 洞 (T4N3) & Ao & ( 5 年10か月) & \\
\hline 7 & 63 & 男 & 舌 (T3N3) & Dc & (4 か月) & M \\
\hline 8 & 70 & 男 & 下顎齿肉 (T4N3) & Ao & （6 年） & \\
\hline 9 & 65 & 女 & 頓 粘 膜 (T2N3) & Dc & ( 3 か月) & $\mathrm{N}+\mathrm{M}$ \\
\hline 10 & 51 & 男 & 舌 $\quad$ (T2N1) & Dc & ( 5 か月) & $T+M$ \\
\hline $11^{*}$ & 63 & 女 & $(\mathrm{T} 2 \mathrm{~N} 1)$ & Dc & (9か月) & $\mathrm{N}$ \\
\hline $12^{*}$ & 79 & 女 & (T1N0) & Ac & (2か月) & $\mathrm{N}$ \\
\hline 13 & 76 & 男 & (T2N0) & Dc & ( 2 か月) & $\mathrm{T}+\mathrm{M}$ \\
\hline 14 & 60 & 男 & ( $22 \mathrm{~N} 0)$ & Dc & ( 8 か月) & $\mathrm{N}+\mathrm{M}$ \\
\hline 15 & 73 & 女 & (T2N0) & $\mathrm{Dc}$ & (11か月) & $\mathrm{N}$ \\
\hline
\end{tabular}

*: 術中破裂症例

Ao: 無癌生存, Ac: 癌法存, Dc: 癌死亡

（転帰：1982年12月31日現在）

表 14 反対側転移・再発症例

\begin{tabular}{|c|c|c|c|c|c|c|}
\hline No. & 年齢 & 性 & 原発部位 $(\mathrm{TN})$ & 臨休経過 & 転㷌 & （術後経過期間） \\
\hline 1 & 65 & 男 & 右 口 底 (T3N1) & $\begin{array}{l}\text { 右 } \mathrm{RND} \rightarrow \text { 左転移 } \\
\rightarrow \text { 左 } \mathrm{RND}\end{array}$ & $\mathrm{Ac}$ & (6か月) \\
\hline 2 & 51 & 男 & 左 舌 (T2N1) & $\begin{array}{l}\text { 左 } \mathrm{RND}+\text { 右 } \mathrm{PND} \rightarrow \text { 右再発 } \\
\rightarrow \text { 右 } \mathrm{RND}\end{array}$ & Dc & (5 か月) \\
\hline 3 & 76 & 女 & 右頓 粘膜 (T2N1) & $\begin{array}{l}\text { 右 } \mathrm{RND} \rightarrow \text { 左転移 } \\
\text { 左 } \mathrm{RND}\end{array}$ & Dc & ( 6 出月) \\
\hline 4 & 73 & 女 & 左上䫁洞 (T3N1) & $\begin{array}{l}\text { 左 } \mathrm{RND}+\text { 右 PND } \\
\rightarrow \text { 右再発 }\end{array}$ & $\mathrm{Dc}$ & ( 6 か月) \\
\hline 5 & 64 & 女 & 左下顎蒌肉（T4N3） & 左 $\mathrm{RND}+$ 右 $\mathrm{PND}$ & Ao & （1 年 8 か月） \\
\hline 6 & 54 & 男 & 右上顎 洞 (T4N3) & $\begin{array}{l}\text { 右 RND+左 PND } \\
\rightarrow \text { 左再発 }\end{array}$ & Dc & (4 か月) \\
\hline 7 & 67 & 男 & 舌 (T4N3) & $\begin{array}{l}\text { 右 RND } \rightarrow \text { 左転移 } \\
\rightarrow \text { 左 RND }\end{array}$ & Dc & (10か月) \\
\hline
\end{tabular}

RND：全頸部郭清術

PND：上頸部郭清術

で死亡した。

\section{考察}

口腔領域は豊富なリンパ組織を含み，それを介してリ ンパ行性転移を生じやすいことから，口腔癌症例の多く にリンパ節転移が生ずると考えられる。

著者らの症例における転移陽性例は, 後発転移13例を
含めて42例あり，60\%の転移頻度であった。これは文献 的に示されている $37.2 \sim 77.1 \%{ }^{3 \sim 8)}$ の転移率の中で，や や高い部類に入るが, 各施設における治療法（特に原発 巣に対する放射線治療の有無)，検索方法，時期などの 違いにより左右されるので，単純には比較できないと考 えられる。

原発部位別では, 舌が最も多く42例中23例を占めてい たが，転移頻度としては，煩粘膜が $75 \%$ （6/8）と最も 
表 15 後発転移死亡症例

\begin{tabular}{|c|c|c|c|c|c|c|c|}
\hline No. & 年路 & 性 & 原発部位 $(T)$ & 転移時期 & リンパ節個数 & 転移部位 & 腫瘍残存部位 \\
\hline $1 *$ & 76 & 男 & $(\mathrm{T} 2)$ & 3 か月 & 2 & $\mathrm{I}+\mathrm{II}$ & $\mathrm{T}+\mathrm{M}$ \\
\hline $2^{*}$ & 60 & 男 & (T2) & 2 か月 & 3 & $\mathrm{I}+\mathbb{I}$ & $\mathrm{N}+\mathrm{M}$ \\
\hline 3 & 78 & 男 & 舌 (T1) & 10か月 & 2 & $\mathbb{I I}+\mathbb{I V}$ & $\mathrm{T}+\mathrm{M}$ \\
\hline $4^{*}$ & 73 & 女 & 舌 (T2) & 5 か月 & 1 & II & $\mathrm{N}$ \\
\hline 5 & 66 & 女 & 上顎洞 (T2) & 10か月 & 3 & I & $\mathrm{T}+\mathrm{M}$ \\
\hline 6 & 69 & 女 & 舌 (T2) & 6 か月 & 2 & I & $\mathbf{M}$ \\
\hline 7 & 62 & 女 & (T2) & 24 か月 & 2 & $\mathrm{II}+\mathrm{IV}$ & $\mathrm{N}+\mathrm{M}$ \\
\hline
\end{tabular}

*:手術時 N3 症例

高かった。これは, 煩粘膜原発例の中に比較的進行癌が 多く含まれ，上・下顎歯肉，買骨といった隣接組織に浸 潤していたためと思われる。宮川ら の)報告でも頓粘膜 癌が最も高かったとされ，粘膜下の笳層を貫通し浸潤し た例では，高い転移傾向を示したと述べている。

原発腫場の進展度と頸部リンパ節転移の様相はほぼ相 関していたが，自験例において，T 1， T 2 が T 3， T 4 より高い転移陽性率を示したことは，今後の検討におい て注目すべき点と思われる。これは後発転移 13 例中, $\mathrm{T} 1$ が 1 例, T 2 が 6 例と多く含まれていたためであろ 5.つまり, 初診時, Stage I, II の初期段階であって も原発巣（特に舌癌症例）の一次治療終了後, 経過中に 転移を生じた例が比較的多かったといらことである．特 に, T 1 例でも深い潰瘍形成や内向性発育を示すもの, T 3 に近いT 2 例などでは, 転移頻度が高まる傾向に あると考えられる.

組織学的分化度については，低分化癌が 4 例と少ない ものの $100 \%$ 転移陽性で，低分化になるにつれて転移頻 度が高くなる傾向が示唆された。 山本ら ${ }^{10)}$ は, 癌組織の 浸潤様式に注目し, 腫瘍の組織学的悪性度を点数化する とともに, 浸潤様式の中で，4 C 型 (索状型)，4 D 型 (び慢型）に高頻度で頸部リンパ節転移が生じ，さらに 後発転移例においても同様の傾向がみられたと述べてい る. 今後, 腫瘍の組織学的悪性度の指標として, 癌浸潤 様式についても検索し，さらに頸部郭清術も含めた治療 法との比較検討を行いたい

頸部リンパ節転移の部位については, 口腔領域の一次 所属リンパ節とされる Level I， II が $76.2 \%$ を占め, また, Level III，IVに転移を認めた例は, 必ず Level I またはIIに転移を伴っていた，文献的8,11) には，直接下 部リンパ節への転移の可能性も示されているが，自験例 ではみられなかった. Level IVに転移を認めた例は 2 例 (舌癌, 後発転移例) であったがともに死亡しており, 一次リンパ節に限局した例と二次リンパ節に進展した例 とでは，生存率において有意の差がみられた。また，同 様に複数領域に進展した例, 複数個のリンパ節転移を生
じた例は，あきらかに予後不良であることを示した．特 に，3個以上の転移リンパ節を認めた例は，極端に生存 率が低下しており，諸家の報告7,12) と一致していた。

自験例に括ける頸部リンパ節転移の正診率は67\%であ り, false negative はないものの, false positive が 23 例 (33\%) みられた。この原因として，1）N1 の診断 基準について，1978年の UICC 分類 ${ }^{1)}$ では，それ以前 の亜分類（ $\mathrm{a}:$ 転移と考えられない， b : 転移と考えら れる）がなくなり，可動性の転移リンパ節を触知するも のは N 1 と総括的に分類された，2）近年発達した超 音波検査などでも，最小 $1.0 \mathrm{~cm}$ の大きさがあれば診断 可能とするものの ${ }^{13)}$. 照射などの影響による反応性のリ ンパ節腫脹との鑑別が必ずしも容易でない，3）術前照 射, 化学療法などにより頸部の洀痕化, 硬化がすすみ, 胸鎖乳突筋下部, 特に上内深頸リンパ節の触知が困難と なりやすい，などが考えられる．現在の新分類 (1987 年) ${ }^{14)}$ では, $3 \mathrm{~cm}, 6 \mathrm{~cm}$ とリンパ節の長径により区別さ れるようになり，触診における固定性の有無は除かれる。 よらになった。 しかしながら，いずれにしても超音波， CT, リンパ節シンチグラフィーなどの画像診断学の向: 上とともに，術前照射などにより修飾された，特に上内， 深頸りンパ節の精査が重要な課題と考えられる.

当科では原則として, 舌癌症例の原発巣に対し進行例 以外は $\mathrm{Ra}$ 針の組織内照射を第一選択としており, リン パ節転移に対しては予防的郭清を行わず，転移を確認し た時点で治療的全頸部郭清術を実施してきた，今回， N0 5 例に対し頸部郭清を行ったが，いずれも原発巣の 手術野に顎下三角が含まれ，さらに筋皮弁による即時再 建上，皮弁茎部を通す目的で郭清手術を実施した症例で あった。われわれの治療成績に扎いて, 転移陽性例と転. 移陰性例との間に有意差はみられなかったが, 後発転移 例の予後はきわめて不良であった．予防的郭清の是非に ついてはすでに多数の報告3 10,15 19)の中でも述べられて きたが, 何よりも大切なのは原発巣の根治 ${ }^{18)}$, さらには 的確な転移リンパ節の早期診断（特に N0 から N1へ 転移する時期の早期発見) であろら。しかし契際には, 
後発転移例で経過観察を続けながらも, 転移を確認し手 術を行うまでの間に，すでに複数個のリンパ節が周囲と 癒着している状態もみられた。また，潜在性転移は舌癌 でTに関係なく約 $23 \%$ 割合でありらるともいわれてい る ${ }^{19)}$. 以上の点を考虑すると，臨床的に転移頻度の高い とされる症例，すなわち内向性発育や浸潤性增殖を示す もの,ささらには，癌浸潤様式など組織学的に悪性度の高 い腫瘍では, 特に厳重な経過観察とともに, 予防的郭清 を再検討する余地があると考えられる。 また，予防的な 放射線治療も有効であるという報告 ${ }^{15)}$ もあるが，今後さ らに検討する必要があろら。

当科では，原則として上頸部郭清は患側全頸部郭清の 反対側併用および全身的条件不良などの特殊例を除き， 単独では行っていない.今回, 反対側に転移した 7 例中 3 例において，反対側上頸部郭清後同側下部に再発した

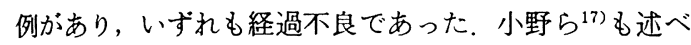
ているよらに, 上頸部郭清後の下部再発例はあきらかに 予後不良であり, 再手術の操作も困難となりやすいので 初回手術時の郭清の範囲および方法の決定は, 十分に考 虑しなければならない。なお，著者らは特に内頸静脈， 胸鎖乳突筋が交叉する部位に転移, 浸潤, 瘉着する例が 多く, 十分な郭清の必要性から全例通常の頸部郭清術を 施行し，また，必要に応じて耳下腺浅葉の一部も郭清範 囲に含めて, 耳下腺近傍のリンパ節転移に対処してき た. 皮膚切開線については当初 $\mathrm{Y}$ 字切開, 変形 $\mathrm{T}$ 字切開 が中心であったが，特に頸部照射例において 3 点縫合と なる部分が皮弁壞死，縫合不全を起こしやすい点などか ら, 最近は Mcfee の平行切開を行らことが多い。これ は, 術野の確保の点ではやや劣るが20), 縫合不全も少な く，審美的にもすぐれた方法と思われる，術後のドレナ ージは特に重要であるが, 最も死腔の生じやすい顎下 部および鎖骨上部にそれぞれ持続吸引チューブを留置 し ${ }^{21)}$, 浮腫, 血腫の予防に対処している.

\section{結語}

1978年〜1987年の10年間に, 当科で頸部郭清術を実施 した口腔扁平上皮癌一次症例70例について, 頸部りンハ 節転移の様相と臨床経過, 治療成績について検討した。

1) 頸部郭清例70例中, 42例 $(60 \%)$ に組織学的に転 移を認め, らち13例は後発転移例であった。

2) 原発部位では, 頓粘膜癌が最も転移頻度が高く, 次いで舌癌, 下顎雨肉癌であった。

3） T分類, Stage 分類と転移陽性率との相関性はみ られなかった。分化度別では，低分化ほど転移しやすい 傾向を認めた。

4）全症例の正診率は67\%, false positive は33\%で あった。

5 ）リンパ節転移部位は，32例 $(76.2 \%)$ が Level I
またはII に限局し，Level IV（鎖骨上窩リンパ節）まで 進展したものは 2 例であった。

6 ）全症例の治療成績は, 原病死 25 例, 他病死 4 例, 生存 41 例で, 5 年累積生存率は $57.9 \%$ であった。

7 ）頸部リンパ節転移の非制御が死亡へつながったと 考えられる症例は 7 例あり，いずれも転移陽珄例であっ た.

8) 経過不良例は, T 4 - N 3 の進展例, 反対側・ Level IVへのリンパ節転移およびリンパ節外への浸潤を 認めた症例であった。 また，リンパ節転移部位，部位 数, 個数と 5 年累積生存率との間に，あきらかな相関性 がみられた。

9 ）転移陰性例, 転移陽性例, 後発転移例の各 5 年累 積生存率は， $60.1 \% ， 54.4 \% ， 14 \%$ で，有意に後発転移 例の経過は不良であった。

10）今後, 特に高悪性度癌の頸部後発転移の制御が重 要課題と思われ，リンパ節転移の診断方法, 予防的郭清 も含めた手術方法の再検討など必要と考える.

本論文の要旨は, 第42回日本口腔科学会総会 (1988 年 6 月，札幌）で発表した。

\section{引用 文 献}

1) UICC: TNM classification of malignant tumors. 3 rd Ed, UICC, Geneva, 1978, p 1726.

2) 日本頭頸部腫瘍学会編：頭頸部癌取扱い規䄪. 第 1 版, 金原出版, 東京, 1982, 62-64面,

3）斋藤利夫, 手島貞一, 他：口腔領域扁平上皮癌 の領域りンパ節転移に関する臨床統計的考察. 日口外誌 25：778-783 1979.

4）新垣 晋：口腔領域悪性腫痬の頸部リンパ節転 移に関する臨床病理学的研究. 日口外誌 25 : 784-797 1979.

5）本間義郎：口腔癌の頸部リンパ節転移に関する 研究. 日外誌 28: 1667-1684 1982.

6) 岡本学, 大関悟, 他: 口腔癌に扣ける頸部 郭清術施行例の検討一頸部 リンパ節転移椂相と 予後一. 日口外誌 31：554-562 1985.

7）野谷健一, 井上農夫男, 他: 当科の頸部郭清例 の検討。日口外誌 32: 602-613 1986.

8) 高田和彰, 遠藤邦彦, 他：口腔領域覀性腫瘳の 頸部リンパ節転移に関する臨床統計的㭘討。日 口外誌 34：872-878 1988.

9）宮川明，小浜源郁，他：口腔癌の頸部リンパ 節転移に関する臨床病理学的検討一特に腫瘍の 浸潤様式との関連について一。 日外誌 29 : 1555-1561 1983.

10）山本悦秀, 宮川明, 他 . 口腔粘膜癌の所属り ン 㦢内浸潤像に関する研究。 日只外誌 30 : 1824-1833 1984 . 
11) Donegan, J.O., Gluckman, J.L., et al.: The role of suprahyoid neck dissection in the management of cancer of the tongue and floor of the mouth. Head \& Neck Surg 4: 209-211 1982.

12) Kalnis, I.K., Leonald, A. J., et al.: Correlation between prognosis and degree of lymph node involvement in carcinoma of the oral cavity. Am J Surg 134: 450-454 1977.

13) 畔田貢: 頭頸部領域における超音波断層像の 診断学的研究. 日口外誌 29：2181-2200 1983.

14) UICC: TNM classification of malignant tumors. 4 th Ed, UICC, Geneva, 1987, p 3032.

15) Nahum, A.M., Bone, R.C., et al.. The case for elective prophylactic neck dissection.
Laryngoscope 87: 588-599 1977.

16）沢木修二：予防的頸部郭清手術の適応。医学の あゆみ 103：567-568 1977.

17）小野 勇, 焦津邦雄, 他: 舌癌治療に打ける钼 部郭清得の評価. 癌の臨床 26: 123-130 1980.

18）野谷健一, 戸塚靖則, 他：頸部郭清訹後の臨床 経過について。 日口外誌 32: 1641-1647 1986.

19) Lee, J.G. and Litton, W.B.. Symposium on malignancy. II occult regional metastasis: carcinoma of the tongue. Laryngoscope 82: 1273-1281 1972.

20）村上 泰：頸部郭清術，頭頸部腫㾤の治療。第 1 版, 医学教育出版, 東京, 1987, 332-349頁.

21）岡部貞夫：頸部郭清㭪。口腔腫瘍の臨床，第 1 版, 書林, 東京, 1985, 143-149頁. 